Final Report

\title{
DEVELOPMENT OF INNOVATIVE TECHNIQUES AND PRINCIPLES THAT MAY BE USED AS MODELS TO IMPROVE PLANT PERFORMANCE
}

By Wayne W. Hanna, Research Geneticist

And

Glenn W. Burton, Research Geneticist

USDA-ARS, Coastal Plain Experiment Station, Tifton, GA 31793

TO: · Department of Energy

SUBJECT: $\quad$ Technical Progress Report for Contract No.

DE-FG02-93ER20099

PREPARED BY: Wayne W. Hanna, Co-Principal Investigator

DATE: $\quad$ June 25, 2000

PERIOD: - $\quad$ February 10, 1993 to January 31, 2001

Copy to: Joe L. Key, Executive Vice President, University of Georgia, Research Foundation, Inc.

DOE Patent Clearance Granted

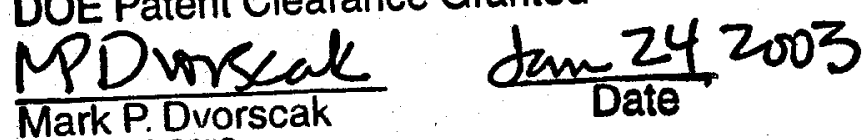

(630) $252-2393$

E-mail-mark.dvorscak@ch.doe.gov

Office of intellectual Property Law

DOE Chicago Operations Office 


\section{DISCLAIMER}

This report was prepared as an account of work sponsored by an agency of the United States Government. Neither the United States Government nor any agency thereof, nor any of their employees, makes any warranty, express or implied, or assumes any legal liability or responsibility for the accuracy, completeness, or usefulness of any information, apparatus, product, or process disclosed, or represents that its use would not infringe privately owned rights. Reference herein to any specific commercial product, process, or service by trade name, trademark, manufacturer, or otherwise does not necessarily constitute or imply its endorsement, recommendation, or favoring by the United States Government or any agency thereof. The views and opinions of authors expressed herein do not necessarily state or reflect those of the United States Government or any agency thereof. 


\section{DISCLAIMER}

Portions of this document may be illegible in electronic image products. Images are produced from the best available original document. 


\section{INTRODUCTION}

A large amount of valuable germplasm for pest resistance, drought tolerance, yield, apomixis, perennial growth habit, and many other agronomic characteristics is present in the primary, secondary and tertiary gene pools of the wild species. Although the germplasm potential of wild species is generally recognized by scientists, limited efforts have been made to transfer and use the wild germplasm in cultivated species. In fact, few programs progress past the production of the initial interspecific hybrids, especially when the tertiary gene pool is involved.

The objectives of this research were to 1) study the cytoplasmic diversity, disease resistance and yield potential of germplasm in the weedy subspecies of the primary gene pool and demonstrate its value, 2) identify mechanism(s) for the transfer of germplasm from the secondary gene pool to the cultivated species and evaluate the plant breeding potential of this germplasm, and 3) transfer gene(s) controlling apomixis form the tertiary gene pool to cultivated pearl millet for the purpose of producing true-breeding hybrids and evaluate this gene pool for useful germplasm.

\section{Accomplishments}

We have been able to develop fundamental methods and techniques for transferring germplasm from wild to cultivated germplasm. In addition, some of the germplasm has been shown to be valuable in plant breeding and the development of commercial cultivars.

Primary Gene Pool- Wild grassy subspecies such as Pennisetum glaucum subspecies monodii have been ignored and considered to be weeds. However, the discovery of dominant genes controlling resistance to a number of leaf diseases (earlier in this project), new male sterility-inducing cytoplasms and possible cytoplasmic effects on seed and plant characteristics indicate that these subspecies deserve further evaluation.

1. The $A_{4}$ cytoplasm (discovered and developed in this project) was used to produce Tift 8593, a $F_{1}$ hybrid cytoplasmic-nuclear male sterile used as female parent (to increase commercial seed production) to produce commercial hybrid, Tifleaf 3. Tifleaf 3 is the most popular pearl millet forage hybrid on the market with over one million pounds of hybrid seed produced each year since 1998.

2. Previous research on the project showed that hybrids with certain cytoplasms from monodii yielded up to $17 \%$ more dry matter than the commercial control. We initiated yield trials with various cross combinations to determine whether the yield increase is due to the cytoplasm or to a cytoplasmic-nuclear interaction but more crosses and testing are needed.

3. Research was initiated in 1997 in Mali to evaluate whether the monodii gene pool 
has resistance to striga and downy mildew, major pests on this crop. Results showed that good genetic resistance is present and that infection is related to time of flowering and downy mildew incidence.

4. The monodii gene pool could potentially contribute nuclear genes for increasing dry matter yields. Research results showed that up to a $31 \%$ increase in dry matter yield is possible by nuclear genes contributed from certain monodii accessions but the grassy nature of this subspecies has to be contended with in the gene transfer process.

5. Over 20 pollinators were crossed onto 40 of the cytoplasmic-nuclear male steriles derived from monodii cyptolasms. Seed set and fertility data indicate a large of amount of cytoplasmic diversity.

6. Rust caused by Puccinia substriata is the most serious disease on pearl millet in the US as well as being a major disease on this crop in Africa and southern India. The primary gene pool has been identified as an excellent source of genetic resistance. Another accession, Tift PS748, has been identified as having good resistance. New systems for managing rust resistance using this new germplasm was studied.

7. A significant response to selection for rust resistance in intermating gene pools from exotic gene pools Tift \#2 and Tift \#5 (developed in this project) was previously observed. Information and techniques derived from these model systems were adopted to develop new strategies for resistance breeding. Dynamic host populations were created which possess increased genetic complexity for resistance to rust. Rust resistance from monodii accession PS 748 was transferred to elite germplasm and included within the dynamic host populations. The resistance in this germplasm has proven to be effective in over three years of field testing.

Secondary Gene Pool- Genetic characteristic on the $A^{\prime}$ genome [similar to the $A$ genome of pearl millet (AA)] of napiergrass ( $A^{\prime} A ' B B$ genomes) is masked by the $B$ genome. Triploid $(2 n=3 x=21)$ hybrids between pearl millet and napiergrass are vigorous but completely male sterile. Hexaploids $\left(2 n=6 x=42, A A A^{\prime} A^{\prime} B B\right)$ produced by doubling the chromosome number of the triploids are male and female fertile. Most of these hexaploids produce $n=21$ (AA'B) gametes but some hexaploid plants also produce $n=7$ ( $A$ and/or $A$ ) gametes. $A$ large number of diploid inbreds with genes and/or chromosomes the A' genome have been developed.

1. Tift 93, developed in this project from the secondary gene pool germplasm has been used to produce a commercial cytoplasmic-nuclear $F_{1}$ male sterile seed parent, Tift 8593, which doubles seed production in commercial fields. Tift 93A is a highyielding (seed) parent to produce high forage-yielding commercial hybrids.

2. New diploid plants from diploid pearl millet $x$ hexaploid(pearl millet $x$ napiergrass) interspecific hybrids have been produced. The diploid plants were characterized for agronomic characteristics. 
3. We initiated evaluation of this germplasm in West Africa.

Tertiary Gene Pool- The tertiary gene pool offers the greatest challenge for germplasm but also some of the greatest opportunities. Characteristics such as apomixis, pest resistance and drought tolerance could have a major impact on food and fiber production around the world.

1. We continued the transfer the gene(s) controlling apomixis from a tertiary gene pool species (Pennisetum squamulatum- $2 n=6 x=54$ ) to cultivated pearl millet(induced tetraploid-2n=4x=28) to produce apomictic pearl millet-like $\left(B C_{8}\right)$ true-breeding plants by seed. Our main objective was to overcome seed set loss in the apomicts after anthesis.

2. In 1998 we observed for the first time seed fertile (over $40 \%$ ) sectors on otherwise fairly seed sterile (less than 10\%) inflorescences of apomictic BC8 plants. These plants and this mechanism (to be determined) have the potential for helping us overcome the seed set loss barrier and in helping us transfer apomixis to the diploid level.

3. We initiated the evaluation of the tertiary gene pool species in West Africa.

Publications listing DOE support during last funding period:

Hanna, W. W. 1997. Registration of Tift 93 pearl millet parental line. Crop Sci. 37:1406.

Hanna, W.W. 1997. Registration of Tift 8593 pearl millet genetic stock. Crop Sci. 37:1412.

Hanna, W.W. 1997. Registration of Tifleaf 3 pearl millet. Crop Sci. 37:1388.

Hanna, W. W. And J.P. Wilson. 1999. Agronomic potential of Pennisetum glaucum subsp. monodii germplasm for forage production. International Sorghum and Millet Newsletter 39: 123-124.

Hanna, W. W. 2000. Total and seasonal distribution of dry matter yields for pearl millet $x$ wild grassy subspecies hybrids. Crop Sci. 40: 1555-1558.

Morgan, R.N., P. Ozias-Akins, and W.W. Hanna. 1998. Seed set in an apomictic BC pearl millet. Int. J. Plant Sci. 159:89-97.

Wilson, J.P., D.E. Hess, B. Cisse, W.W. Hanna, and O.Youm. 1998. Striga hermonthica infection of wild Pennisetum germplasm is related to time of flowering 